\title{
MENINGKATKAN KETERAMPILAN LAY UP PERMAINAN BOLA BASKET DENGAN PENERAPAN METODE PEMBELAJARAN KOOPERATIF TIPE STUDENT TEAM ACHIEVMENTS DIVISIONS (STAD) SISWA KELAS X MIPA SMA NEGERI 1 BENGKULU TENGAH
}

\author{
Inten Pridani \\ PENJAS FKIP UNIB, e-mail: intenpridani@gmail.com
}

Bayu Insanistyo

Universitas Bengkulu

Arwin

Universitas Bengkulu

Defliyanto

Universitas Bengkulu

\begin{abstract}
Abstrak
Penelitian ini bertujuan untuk mengetahui peningkatan keterampilan lay up.dalam permainan bola basket. Metode yang di pakai adalah pembelajaran kooperatif tipe Student Team Achievments Division (STAD). Jenis Penelitian adalah penelitian tindakan kelas. Penelitian di lakukan pada siswa kelas X MIPA SMA Negeri 1 Bengkulu Tengah yang berjumlah 36 siswa. Pada penelitian ini melihat hasil uji pra siklus, siklus $1 \mathrm{dn}$ siklus 2 serta lembar observasi guru dan siswa. Nilai tes uji pra siklus di dapat 33,3\% yang mendapat nilai baik artinya masih sangat kurang dalam keterampilan lay up permainan bola basket. Pada siklus 1 di dapat 69,4\% terjadi peningkatan keterampilan lay up pada permainan bola basket namun belum mencapai KKM dan dilihat dari observassi guru mendapat nilai $72 \%$ dan observasi siswa 65\%. Pada siklus 2 didapat nilai tes sebesar 83,3\%, sedangkan lembar observasi guru sebesar $84 \%$ dan lembar observasi siswa sebesar $80 \%$ semua telah menunjukan ketuntasan nialai atau $\mathrm{kkm}$ 75\%. Dari nilai tes siklus 2 dapat disimpulan pembelajaran teknik lay up dengan menggunakan model pembelajaran kooperatif tipe Student Team Achievments Division (STAD) dapat meningkatkan ketermpilan lay up permainan bola basket dan meningkatkan semangat belajar siswa. Peningkatan ini dikarenakan siswa bersemangat dalam proses belajar dan saling membantu didalam kelompok masing.
\end{abstract}

Kata kunci: Metode Kooperatif Tipe STAD, Keterampilan lay up , Permainan Bola Basket

\begin{abstract}
This study aims to determine the improvement of lay up skills in basketball games. The method used is cooperative learning type Student Team Achievments Division (STAD). Types of Research is a classroom action research. The research was conducted on the students of class X.MIPA SMA Negeri 1 Bengkulu Tengah, wihch amounted to 36 students. This study looks at the results of pre-cycle test, cyle 1 and cycle 2 and teacher and student observation
\end{abstract}


sheet. The value of pre-cycle test in 33,3\% can get a good value means still very less in the skills lay up basketball game. In the 1st cycle in 96,4\% there can be increased lay up on basketball games but have not reached KKM and viewer from the observasition of the teacher gets $72 \%$ and studebnt observation $65 \%$ in the 2 nd cycle obtained the tes value of $88,3 \%$, while the teacher's observation sheer of $84 \%$ and student observation sheer of $80 \%$ all has shown maked kialty or KKM 75\%. From the value of the test cycle 2 can be conclueded the learning of lay up techniques by using the cooperative learning type Student Team Achievments Division (STAD) can increase the lay-laying of basketball games and improve the students' learning spirit. This increase is because students are excited in the learning process and help each other in their group.

Keywords: STAD Type Co-operative Method, Skill lay up, Basketball Game

\section{PENDAHULUAN}

Didalam UUD No.20, Tahun 2003. Pasal 3 yang menyebutkan, Pendidikan nasional berfungsi mengembangkan kemampuan dan membentuk watak serta peradaban bangsa yang bermartabat dalam rangka mencerdaskan kehidupan bangsa, bertujuan untuk berkembangnya potensi peserta didik agar menjadi manusia yang beriman dan bertakwa kepada Tuhan Yang Maha Esa, berakhlak mulia, sehat, berilmu, cakap, kreatif, mandiri, dan menjadi warga negara yang demokratis serta bertanggung jawab.

Berdasarkan isi dari Undangundang No. 20, Tahun 2003. Pasal 3 diatas dalam usaha untuk mencapai tujuan tersebut, dibutuhkan seorang pendidik yang berkualitas sehingga dalam pola pembelajaran yang diajarkan dalam proses belajar mengajar dapat mencapai tujuan yang diinginkan. Dalam proses belajar mengajar, dibutuhkan seorang pendidik yang mampu berkualitas serta diharapkan dapat mengarahkan anak didik menjadi generasi yang kita harapkan sesuai dengan tujuan dan cita-cita bangsa. Untuk itu, guru tidak hanya cukup menyampaikan materi pelajaran semata, akan tetapi guru juga harus pandai menciptakan suasana belajar yang baik, serta juga mempertimbangkan pemakaian metode dan strategi dalam mengajar yang sesuai dengan materi pelajaran dan sesuai pula dengan keadaan anak didik. Keberadaan guru dan siswa merupakan dua faktor yang sangat penting di mana diantara keduanya saling berkaitan. Kegiatan belajar siswa sangat dipengaruhi oleh kegiatan mengajar guru, karena dalam proses pembelajaran guru tetap mempunyai suatu peran yang penting dalam memberikan suatu ilmu kepada anak didiknya. Salah satu masalah yang dihadapi guru dalam menyelenggarakan pelajaran adalah bagaimana menimbulkan aktifitas dan keaktifan dalam diri siswa untuk dapat belajar secara efektif. Sebab, keberhasilan dalam suatu pengajaran sangat dipengaruhi oleh adanya aktifitas belajar siswa.

Olahraga merupakan suatu sarana untuk bisa menciptakan rasa siswa untuk bisa mengembangkan bakat mereka, misalnya di sekolah, sekolah itu merupakan suatu tempat dimana terdapat minat dan bakat siswa dalam bidangnya masing masing misalnya dalam olahraga. Harapan dari semua pihak teruatama dari peneliti yakni ingin meningkatkan tingkat kemampuan siswa dalam masing masing cabang olahraga, misalnya olahraga Bola basket.

Olahraga bola basket harus memerlukan teknik dasar yang baik agar 
bisa memberikan hasil yang baik dalam suatu pola permainan. Ada beberapa teknik dasar dalam perminan bola basket, yakni Dribling, Shotting, Passing teknik dasar itu harus bisa dikuasai oleh seorang atlet atau pemain bola basket. Seperti halnya dalam proses pembelajaran disekolah. Banyak siswa yang kurang menguasai teknik dasar tersebut dengan baik, misalnya shotting teknik ini merupakan suatu teknik dasar yang harus dikuasai oleh seorang pemaian bola basket.

Sebuah prestasi dapat diraih apabila tim dapat memenangkan pertandingan dengan memasukan bola kekeranjang lawan sebanyak-banyaknya. Nilai dari permainan bola basket di peroleh dari hasil kerjasama regu atau tim yang melakukan gerakan dribbling, passing, dan terkahir dengan menembak ke keranjang lawan. Dalam hal ini teknik merupakan salah satu pondasi dasar bagi seseorang untuk orang dapat bermain bola basket. Dari sekian banyak teknik yang di latih salah satunya adalah menembak, karena menembak adalah akhir dari serangan. berdasarkan uraian di atas dapat di katakan, menembak mempunyai fungsi penting dalam permainan bola basket, hal ini di sebabkan kemenangan satu regu dalam bermain bola basket ditentukan oleh jumlah poin yang dihasilkan melalui menembak bola ke dalam keranjang.

Pada permainan bola basket mempunyai teknik dasar shotting salah satunya lay up. Tembakan yang di lakukan di ring basket, setelah menggiring bola. Untuk melakukan lompat yang tinggi dalam gerakan lay up, maka dibutuhkan kecepatan pada tiga atau empat langkah terakhir. Sangat penting untuk menjaga agar kepala tetap tegak sewaktu akan dan selama melakukan tembakan. Bola harus di lempar dekan kepapan dengan pergelangan tangan dan jari. Dan seharusnya menyentuh papan terlebih dahulu baru masuk ke dalam ring.

Ditingkat sekolah menengah pertama teknik dasar permainan bola basket baru saja diperkenalkan bagaimana dribling, passing, serta shooting. Dalam suatu pertandingan bola basket sangat diperlukan kerja sama yang baik. Untuk melakukan kerja sama yang baik sangatlah diperlukan penguasaan teknik shotting yang baik, agar kerja sama yang akan dibangun dan berhasil mencetak poin. Salah satu tipe atau teknik shotting adalah lay up. Teknik melakukan lay up harus dilatih secara terus menerus, terutama pada tingkat sekolah menengah pertama, yang baru mengenal permainan bola besar basket.

Pada tanggal 30 Januari 2017 observasi awal dilakukan peneliti di SMA Negeri 1 Benteng. Dari hasil observasi pada saat pembelajaran bola basket, masih banyak siswa yang belum melakukan lay up dengan baik pada saat permainan bola basket, khususnya pada siswa yang diamati pada saat itu yaitu kelas X.MIPA. Hal ini dapat terjadi karena kurangnya minat siswa akan permainan bola basket ataupun metode pembelajaran yang diberikan guru olahraga kurang memotivasi siswa untuk belajar bersungguh-sungguh.

Pada observasi awal peneliti melihat proses pengajaran dan berdiskusi dengan guru olahraga SMA Negeri 1 Benteng, masih banyak siswa yang belum paham melakukan lay up, dan masih salah dalam melakukannya. Dari permasalahan ini, peneliti sangat tertarik mengangkat nya untuk penelitian. Siswa yang melakukan lay up, hanya 12 orang yang mendapat nilai cukup, selebihnya 24 siswa masih banyak yang salah dalam melakukan teknik lay up. Kebanyak siswa hanya asal melakukan shotting pada ring, terutama pada saat dilakukan permainan bola basket. Permasalahan ini harus dicari solusinya agar meningkatkan keterampilan siswa dan 
kedepannya dapat meningkatkan prestasi olahraga SMA Negeri 1 Benteng, terutama dibidang bola basket. Oleh karena itu penulis akan memberikan tindakan dengan menggunakan metode Student Teams Achievment Division (STAD) demi meningkatkan kemampuan lay up pada permaian bola basket tersebut.

Metode STAD merupakan bagian dari model pembelajaran kooperatif yang menurut Riyanto, (2009:267), pembelajaran kooperatif adalah model pembelajaran yang dirancang untuk membelajarkan kecakapan akademik (academic Skill), sekaligus keterampilan sosial (social Skill) termasuk interpersonal skill. Sedangkan menurut Menurut Trianto (2011 : 133) Pembelajaran kooperatif secara umum menyangkut teknik pengelompokan yang di dalamnya siswa bekerja terarah pada tujuan belajar bersama dalam kelompok kecil yang umumnya terdiri dari empat atau lima siswa. Pembentukan kelompok didasarkan pada pemerataan karakteristik psikoogis individu, yang meliputi kecerdasan, kecepatan belajar, motivasi belajar, perhatian, cara berpikif, dan daya ingat. Sedangkan metode STAD mempunyai pengertian "Pembelajaran kooperatif tipe STAD adalah salah satu tipe dari pembelajaran kooperatif dengan menggunakan kelompok-kelompok kecil dengan jumlah anggota tiap kelompok 5-6 orang siswa secara heterogen. Diawali dengan penyampaian tujuan pembelajaran, penyampaian materi, kegiatan kelompok, kuis dan penghargaan kelompok" (Trianto, 2011: 52)

Menyikapi dari permasalahan tersebut, peneliti kemudian berusaha untuk meningkatkan keterampilan teknik lay up siswa, dan peneliti akan mengankat judul penelitian "Meningkatkan Keterampilan lay up Bola Basket Dengan Metode Pembelajaran Kooperatif Tipe Student Team Achievment Divisions (STAD)
Pada Siswa kelas X.MIPA. SMA Negeri 1 Benteng.

Tujuan dari penelitian ini adalah untuk mengetahui peningkatan kemampuan teknik lay up pada permainan bola basket siswa kelas X.MIPA SMA Negeri 1 Benteng dengan menggunakan metode pembelajaran kooperatif tipe Student Team Achievment Divisions (STAD.

\section{METODE}

Jenis penelitian yang dilakukan pada penelitian ini adalah Penelitian tindakan kelas. Penelitian tindakan kelas adalah cara suatu kelompok atau seseorang dalam mengorganisasi suatu kondisi sehingga mereka dapat mempelajari pengalaman mereka dan membuat pengalaman mereka dapat diakses oleh orang lain (Sukardi, 2003:210). Reflektif dengan melakukan tindakan-tindakan tertentu agar dapat memperbaiki dan atau meningkatkan kualitas proses dan hasil pembelajaran yang diselenggarakan secara profesional.

Serta PTK memiliki peranan yang sangat penting dan strategis untuk meningkatkan mutu pembelajaran apabila diimplementasikan dengan baik dan benar. Di implementasikan dengan baik artinya phak yang terlibat dalam PTK (guru) mencoba dengan sadar mengembangkan kemampuan dalam menditeksi dan memecahkan masalah-masalah yang terjadi dalam pembelajaran di kelas melalui tindakan bermakna yang di perhitungkan dalam memecahkan masalah dan memperbaiki situasi dan secara cermat mengamati pelaksanaanya untuk mengukur tingkat keberhasilan. (Kunandar 2011:41)

Dari pengertian PTK diatas dapat ditarik kesimpulan bahwa PTK merupakan suatu tindakan penelitian kelas yang dilaksanakan pada satu kelas atau objek yang diteliti saja dengan tujuan 
peningkatan atau perbaikan praktek pembelajaran, pengembangan keterampilan guru berdasarkan persoalan pembelajaran yang dihadapi guru dan meningkatkan hasil belajar.

Penelitian delakukan penelitian yaitu di SMA Negeri 1 Bengkulu Tengah. Penelitian ini dilaksanakan pada semester genap tahun ajaran 2016 - 2017. Yang dijadikan subjek penelitian dalam hal ini siswa kelas X.MIPA SMA Negeri 1 Bengkulu Tengah tahun ajaran 2016/2017, yang berjumlah 36 orang siswa. Data yang akan diperoleh dari penelitian ini adalah data kualitatif dan data kuantitatif.

Data yang diambil antara lain uji tes praktek, observasi lapangan dan dokumentasi. Untuk observasi, dibuat lembar pengamatan /lembar observasi untuk penilaian aktifitas siswa selama pembelajaran berlangsung. Sedangkan untuk observasi terhadap aktifitas guru pada saat proses pembelajaran menggunakan lembar penilaian observasi aktifitas guru.

\section{HASIL DAN PEMBAHASAN Hasil}

Berdasar pada pelaksanaan proses meningkatkan keterampilan lay up bola basket menggunakan model pembelajaran STAD pada siswa kelas X MIPA di SMA Negeri 1 Bengkulu Tengah pada siklus 1 jumlah indikator yang guru lakukan pada proses belajar mengajar disiklus 1 yaitu 18 item atau mendapat presentase (72\%). Begitu juga dengan jumlah indikator yang siswa ikuti pada proses belajar mengajar disiklus ke 1 yaitu 13 item atau mendapat presentase (65\%) belum tuntas belajar. Sedangkan menilaian tes lay up sebanyak 25 siswa dimana sebesar $(69,4 \%)$ dan belum dinyatakan tuntas.

Pada siklus ke 2 jumlah indikator yang guru lakukan pada proses belajar mengajar disiklus ke dua yaitu 21 item atau mendapat presentase (84\%). Begitu juga dengan jumlah indikator yang siswa ikuti pada proses belajar mengajar disiklus ke dua yaitu 16 item atau mendapat presentase $(80 \%)$ telah tuntas belajar. Hasil tes lay up meningkat menjadi $(83,3 \%)$ sebanyak 30 siswa. Berdasarkan hasil tersebut maka dapat disimpulkan bahwa penelitian ini telah mencapai standar indikator keberhasilan yang ditetapkan yaitu (75\%).

\section{Pembahasan}

Berdasarkan prosedur penelitian tindakan kelas yang sudah dirancang dan dilaksanakan dengan sistematis, peneliti dapat mengumpulkan data penelitian yang mungkin dapat berupa informasi penting dari hasil penelitian. Penerapan model pembelajaran kooperatif tipe STAD pada pembelajaran teknik lay up dalam permainan bola basket memberikan dampak positif kepada siswa. Dari prosesnya observasi awal hingga pelaksanaan pada siklus 2 terjadi peningkatan pada tiap pertemuannya.

Pada observasi awal peneliti memberikan tes penilaian terhadap kemampuan teknik lay up pada siswa, namun belum diberikan materi pembelajaran teknik lay up. Hasil dari nilai tes siswa, sebagian besar belum menguasai teknik lay up yang baik. Dari 36 siswa kelas X.MIPA SMA Negeri 1 Bengkulu Tengah yang bisa menguasai teknik lay up dengan baik sebanyak 12 siswa (33,3\%), siswa dalam kategori cukup 8 siswa ( $22,8 \%$ ) serta siswa yang belum mampu menguasai sebanyak 16 siswa $(44,4 \%)$.

Pada siklus 1 diberikan materi pembelajaran teknik lay up. Peneliti bersama guru Penjaskes menyusun rencana pembelajaran dalam memberikan materi teknik lay up. Pada penelitian ini peneliti memberikan model pembelajaran kooperatif tipe STAD (student teams achievment divisions). Pada siklus 1 terjadi 
peningkatan setelah diberikan materi teknik lay up dengan model pembelajaraan STAD. Siswa yang telah mampu atau mendapatkan nilai kriteri baik sebanyak 25 siswa (69,4\%). Terjadi peningkatan dari hasil tes awal yang hanya 13 siswa. Pada nilai kategori cukup sebanyak 7 siswa $(19,4 \%)$ dan kategori kurang sebanyak 4 siswa (11,11\%).Meskipun terjadi peningkatan pada siklus 1 , namun secara keseluruhan kemampuan siswa dengan kriteria baik belum mencapai minimal 75 , yaitu nilai KKM mata pelajaran Penjaskes di SMA Negeri 1 Bengkulu Tengah. Hal ini perlu ditingkatkan lagi, terutama pada siswa yang masih mendapatkan nilai kategori cukup dan kurang, untuk itu penelitian dilanjutkan pada siklus 2 .

Dengan berdiskusi kembali dengan teman sejawat dan guru penjaskes sekolah, bersama-sama membuat perencanaan pada siklus 2 . Perencanaan berupa mengidentifikasi hasil data siklus 1 , kemudian mencari solusi mengatasi kelemahan-kelemahan dari tindakan siklus 1. Peneliti membagi siswa yang sudah mampu menguasai teknik lay up ke dalam tiap - tiap kelompok siswa. Hal ini bertujuan untuk agar siswa dapat saling memotivasi siswa yang masih kurang dapat bertanya langsung kepada siswa yang sudah mampu dalam kelompoknya.

Pada siklus 2 hasil yang didapat mengalami peningkatan. Siswa yang mendapat nilai kategori baik sebanyak 30 siswa $(83,3 \%)$, siswa dangan nilai kategori cukup 4 siswa( $11,11 \%)$, dan siswa dengan kategori nilai kurang 2 siswa (5,55\%). Dari hasil pada siklus 3 ini, dirasa peneliti sudah cukup, karena secara keseluruhan nilai dari siswa telah mencapai KKM dengan nilai minimal 75 sebesar $83,3 \%$ dari seluruh jumlah siswa.

\section{PENUTUP}

Simpulan
Seluruh rangkaian penelitian tindakan kelas (PTK) di SMA Negeri 1 Bengkulu Tengah telah selesai dilaksanakan, maka hasil penelitian dapat disimpulkan sebagai berikut :

1. Penerapan model pembelajaran tipe STAD dapat meningkatkan keterampilan teknik lay up siswa dalam pada permainan bola basket.

2. Dari hasil tes awal yang dilaksanakan hingga tes siklus 2 menunjukkan peningkatan, dimana pada tes awal tingkat ketuntasan belajar siswa secara keseluruhan sebesar 33,3 \%. Pada siklus 1 meningkat menjadi 69,4\% dan pada siklus 2 meningkat menjadi 83,33\% dengan artinya secara keseluruhan nilai siswa sudah mencapai KKM.

3. Dengan model pembelajaran menggunakan tipe STAD, dapat meningkatkan kemapuan teknik lay up pada permainan bola basket, juga dapat memperbaiki proses pembelajaran. Dengan model pembelajaran ini kemauan siswa akan keberhasilan dalam belajar menjadi meningkat, sesama siswa dapat saling bertanya dan saling memotivasi siswa yang belum menguasai. Kemudian dengan kreasi dalam pembelajaran dibuat suatu kopetisi memberikan motivasi terhadap siswa untuk menuasai materi pembelajaran dikarenakan akan diberikan suatu penghargaan kelompok yang memenagkan kompetisi.

\section{Saran}

Dari hasil penelitian ini, peneliti dapat memberikan saran sebagai berikut:

1. Pemberian materi pembelajaran Jasmani di SMA Negeri 1 Bengkulu Tengah sebaiknya dikondisikan dengan karakteristik anak-anak. Pemeberian motivasi harus dilakukan untuk meningkatkan kemauan belajar siswa. 
2. Dapat menjadi sebagai masukan kepada guru menggunakan model pembelajaran pada penelitian ini untuk meningkatkan keberhasilan siswa dalam pembelajaran penjaskes dalam permainan olahraga selain bola basket.

3. Perlunya pengadaan peralatan, sarana dan prasarana untuk mata pelajaran penjaskes, dikarenakan perlatan sangat dibutuhkan untuk mendukung keberhasilan pembelajaran.

\section{DAFTAR PUSTAKA}

Aqib.Z, Ali M. (2016). Kumpulan Metode pembelajaran. Bandung : CV.Yrama widya.

Kunandar. 20013. Metodologi Penelitian Pendidikan. Jakarta : Bumi Aksara.

Rianto, (2009), pembelajaran kooperatif. Jakarta: Prestasi Pustaka Publisher.

Sukardi. (2003),Pendidikan Jasmani Olahraga Kesehatan. Erlangga. Jakarta.

Tangkudung, James. (2012). Kepelatihan Olahraga Pembinaan Prestasi Olahraga. Jakarta: Cerdas jaya

,(2016).Macam-macam

Metodologi Penelitian. Jakarta: Lensa Media Pustaka Indonesia

,(2018). Sport Psychometrics Dasar-dasar dan instrument Psikometri. Depok :Rajagrafindo persada

Trianto.(2011). Model-Model Pembelajaran Inovatif Berorientasi Konstruktivistik: Konsep,Landasan Teoritis-Praktis dan Implementasinya. Jakarta: Prestasi Pustaka Publisher. 